\title{
Technique and Quality Translation of Idhafi Phrases in The Poetry of Asyhadu An La Imraata Illa Anti by Nizar Qabbani
}

\author{
${ }^{1}$ Lalu Muhammad Faesal Asy'ari; ${ }^{2}$ Yoyo \\ Email : 1aanasyari5@gmail.com, 22yoyo@bsa.uad.ac.id \\ 1,2 Bahasa dan Sastra Arab, Universitas Ahmad Dahlan, Yogyakarta, Indonesia
}

\section{ARTICLE INFO}

Article history

Received 4 December 2021

Revised 22 December 2021

Accepted 27 December 2021

Keywords

Translation Technique,

Translation Quality,

Idhafi Phrases,

Poetry,

Nizar Qabbani.

\section{ABSTRACT}

The translation process is an activity of transferring one language to another. From this translation process, the researchers try to examine the translation techniques and translation quality of the collection of translation poems by Nizar Qabbani entitled Asyhadu An La Imraata Illa Anti. The methodological foundation that the researcher uses is a qualitative method. In this study, the researcher found 160 Idhafi phrases which were translated using 15 translation techniques, and 2 translation techniques that had good quality in conveying the intent, message, and purpose to the reader into the target language. That is, the equivalent technique generally has the highest value on three aspects of assessment for the quality of translation, among others, the accuracy aspect has a score of $83.3 \%$, then the acceptability aspect has a score of $85.7 \%$, and in the readability aspect, it has a score of $78.6 \%$ for further research. The researcher can discuss in more detail the translation method of Nizar Qabbani's Poetry.

This is an open access article under the CC-BY-SA license.

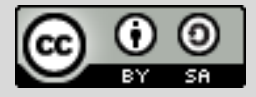

\section{Introduction}

Translation as a discipline and process develops rapidly (Bassnett, 2013). Every country tries to translate literary and significant works to be introduced to other nations (Yan \& Huang, 2014). There are motivations behind the translation movement, such as adopting new sciences from other countries. In the Arab world, the translation movement begins in the 1820s by translating some significant works from Western intellectual traditions (Abu Lughod) (Lughod, 
1963; Yoyo, Ahimsa Putra, Heddy Shri Manshur, \& Muti'ah, 2012). This translation movement is one of the critical factors for the Arab renaissance (Yoyo, 2018; Yoyo \& Mukhlis, 2019).

One of the significant works that need to be translated is poetry. As one of the classical forms of Arabic literature, poetry has an important place in Arab society (Zeidan \& Moreh, 1979). Since its classical era, a market called 'Ukaz, was used for the poetry competition (Al-Ghadeer, 2007). The competition winner will have an honorable place because its poetry will be attached to the Ka'bah wall. Therefore, poetry in Arab society presents the competence of composing beautiful lyrics and brings a poet into a high-level position in society (Gruendler, 2003). Poetry itself is is a form of a poet's imagination of the incidents he has experienced or incidents in his society (White, 1978).

In this study, the authors are interested in studying poetry composed by a famous Arab poet Nizar Qabbani. He is a Syrian poet and diplomat and was born in Damascus in 1923 and died in 1998 (Doğru, 2017). Nizar Qabbani created a lot about his feelings for women through his poetry. His feelings about his love for a woman, which is described so beautifully, are found in one of the long poetry collections he wrote entitled Asyhadu An La Imraata Illa Anti.

Nizar Qabbani's collection of poems entitled Asyhadu An La Imraata Illa Anti is a poem that describes and tells the figure of the woman he loves through a variety of beautiful figurative language and makes it interesting to research (Moradi \& Karimi, 2012). The poem is rich in meaning by sharing the attractive choice of words or figures of speech that Nizar Qabbani uses in his poetry. This collection of poems was successfully translated into Indonesian with a book entitled "Aku Bersaksi Tiada Perempuan Selain Engkau" translated by Musyafiqur Rahman and published by Basabasi Yogyakarta in 2018.

From this book, authors are interested in researching the translation process or transferring meaning from Arabic into Indonesian through translation techniques. Within this paper, the authors used the translation technique of Molina and Albir that consist of 18 translation techniques including literal; calque; descriptive analysis; modulation; discursive creation; compensation; description; particulation; reduction; substitution; variation; transposition; borrowing; linguistic amplification; common equivalent; generalization; and adaptation (Molina \& Albir, 2002).

There are relevant previous studies on the topic. First, a thesis was written by Arief Abdillah Fikri from the University of Muhammadiyah Surakarta 2014 entitled Analysis of Conjunctions in Translating Surat An Nisa. The study analyzes the types of conjunctions and explains the meaning of the conjunctions in An Nisa's letter. Second, a thesis written by Miftahul Huda, entitled Study of Phrases and Sentences in the Translation of the Al-Quran Surah Al Mulk, from 
the University of Muhammadiyah Surakarta 2011. The study aims to describe phrases and describe various sentences in the translation of the Qur'an Surah Al Mulk.

Third, a thesis written by Hidayatur Rosyidah entitled Relation of the Meaning of Clauses in Compound Sentences in the Translation of Surah Luqman from the University of Muhammadiyah Surakarta 2019. The study aims to describe the form of meaning relations in the translation of Surah Luqman. The study concluded that conjunctions are used to make meaning relations, define the meaning of the translation of the Surah Lukman.

Forth, two papers entitled "Technique and Quality Translation of Idhafi in The Matan Hadits of Arba'in al-Nawawi" and "Amplification and Description Techniques in the Translation of Arabic Phrases in Matan Al-Ghayah wa Al-Taqrib." The two papers used the translation techniques of Molina and Albir and have the same conclusions that there are dominant techniques used in the translation process in the same cases. This conclusion assumes that in some instances, the translator appointed more original terms from the sourse language since there are similar ideas of the targeted language (Faturrahman, Yoyo, \& Zaini, 2020; Lestari, Yoyo, \& Zaini, 2020).

In a specific way, the authors aim to analyze techniques and the quality translation of the Idhafi phrases from the source language (SL) to the target language (TL) by taking the data from Asyhadu An La Imraata Illa Anti.

\section{Method}

This research was conducted using a qualitative method with a descriptive approach because the results of qualitative research are more inclined to meaning than generalization and data accumulation techniques. Researchers examined triangulation because the data analysis used was inductive/qualitative. The researchers used secondary data sources such as dictionaries, books, and the internet in this study. Meanwhile, the primary data sources related to research and the researcher's translation process refer to a collection of Nizar Qabbani's poems entitled Asyhadu An La Imraata Illa Anti.

Besides, to measure the quality translation of the poetry, the authors distributed questionnaires to 42 respondents with the following criteria: 1) students of Arabic Language and Literature at Ahmad Dahlan University at the $5^{\text {th }}$ semester; 2) have already taken a course in translation theory; and 3) mastering the targeted language (Indonesian).

\section{Results and Discussion}

\section{Literal Translation}

Data 1: Poetry 1 "Prolog", page 39

$$
\text { أقم مؤتي إليك على شكل شعر }
$$




Kupersemebahkan kematianku padamu, dalam bentuk
Poetry

In this data, there are Idhafi phrases which are translated using the literal translation technique, namely the words شعر which means in the dictionary is "bentuk" and the word means "puisi" (Al-Munawwir, 1997).

The translator translates word for word, which is done to convey the message properly and correctly.

Data 2: Poetry 2 "Pengadilan", page 40

\begin{tabular}{|c|r|}
\hline Sل نهد ... أنا أذورته & SL \\
\hline Dan Setiap buah dada, kutambah gejolaknya & TL \\
\hline
\end{tabular}

On the word, كل which means in the dictionary is "setiap" and the word نهد which means "buah dada" (Al-Munawwir, 1997). This literal translation has attractive meaning to the targeted reader because the use of the original purpose of the SL is more adaptable for the reader.

Here are the results of the quality of translations carried out by 42 respondents.
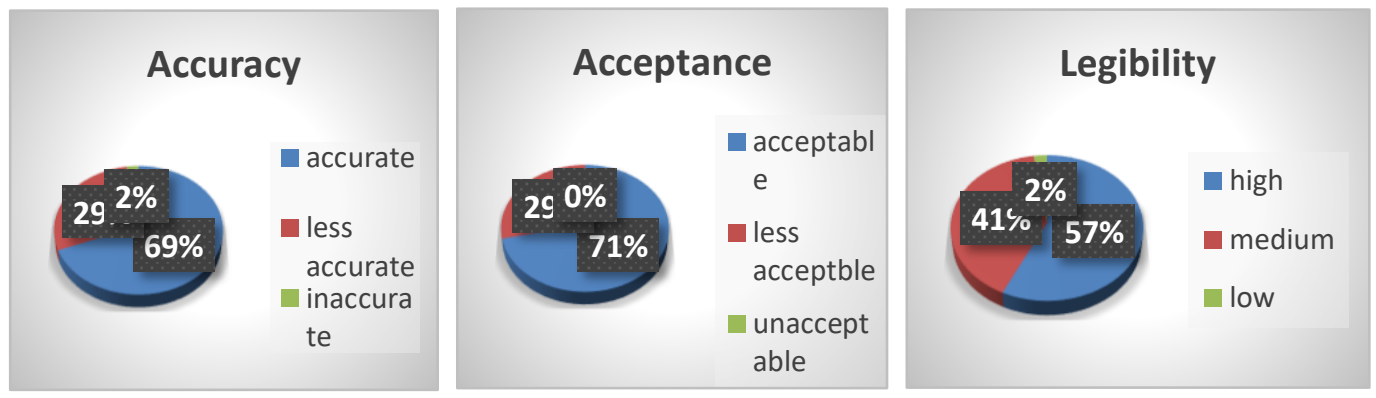

Figure 1. Quality translation of data 1 and 2.

Figure 1 shows that as many as 29 respondents (69\%) rated the translation using the literal translation technique as very accurate. In addition, as many as 12 respondents (28.6\%) rated the translation as less authentic, and one respondent (2.4\%) considered it inaccurate. Then on the Acceptance aspect, 30 respondents (71.4\%) rated it acceptable, 12 respondents (28.6\%) thought it less acceptable, and no respondents $(0 \%)$ considered it unacceptable. Then on the aspect of legibility. As many as 24 respondents (57.1\%) rated the legibility aspect as high, 17 respondents $(40.5 \%)$ rated it as moderate legibility, and only 1 respondent $(2.4 \%)$ rated low legibility.

\section{Adaptation}

Data 3: Poetry 2 "Pengadilan", page 41

\begin{tabular}{|l|r|}
\hline فكل مذبوحة دافع عن دمها & SL \\
\hline Setiap yang terbantai, aku bela darahnya & TL \\
\hline
\end{tabular}


In this data, there are Idhafi phrases which are translated using the Adaptation technique, namely, مذبوحة Word in the dictionary has meaning "yang tersembelih" (Al-Munawwir, 1997).

In the case of translating Idhafi phrases (مذبوحة), the translator replaces the cultural elements of the source language (SL) with the cultural aspects of the target language (TL). That is the meaning of the word "tersembelih", becomes "terbantai" because the translator replaces cultural elements that have the same characteristics as the target language (TL).

Data 4: Poetry 2, "Aku bersaksi tiada perempuan selain engkau", page 47

\begin{tabular}{|c|r|}
\hline وقدمت لي لبن العصفور & SL \\
\hline Yang menyuguhiku susu burung pipit & TL \\
\hline
\end{tabular}

On the word العصفور in the dictionary has meaning "burung kutilang" (Al-Munawwir, 1997).

In the case of translating Idhafi phrases (العصفور), the translator replaces the cultural elements of the source language (SL) with the cultural aspects of the target language (TL). That is the meaning of the word "burung kutilang", becomes "burung pipit" because the translator replaces cultural elements that have the same characteristics as the target language (TL).

Here are the results of the quality of translations carried out by 42 respondents.
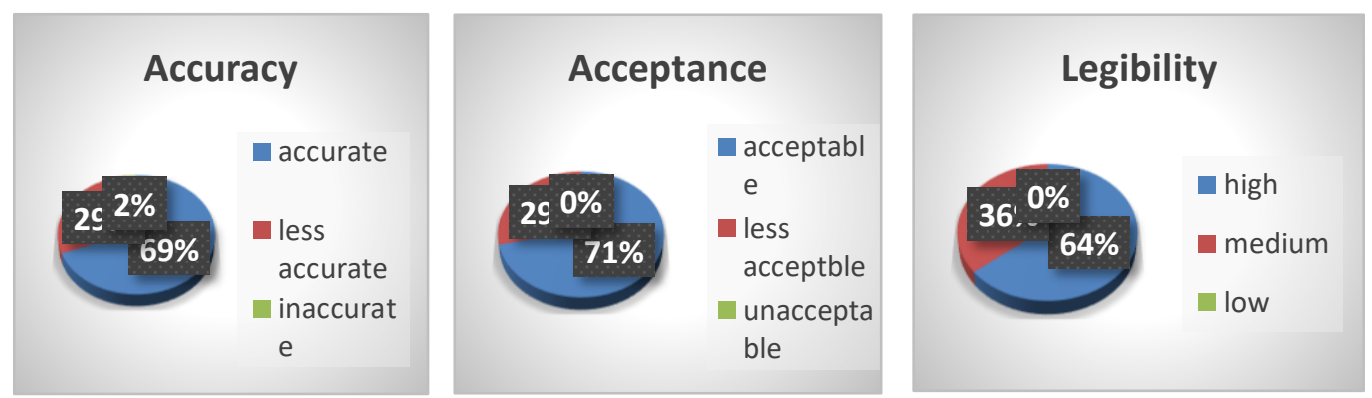

Figure 2. Quality translation of data 3 and 4.

Figure 2 shows that 29 respondents (69\%) rated the translation very accurate. In addition, as many as 12 respondents $(28.6 \%)$ rated it less accurate and 1 respondent $(2.4 \%)$ rated it inaccurate, then on the Acceptance aspect, 30 respondents (71.4\%) considered it acceptable, 12 respondents (28.6\%) considered less acceptable, and no respondents (0\%) considered it unacceptable. In the legibility aspect, as many as 27 respondents (64.3\%) rated legibility as high, 15 respondents (35.7\%) rated it as having a moderate legibility level, and no respondent $(0 \%)$ rated it as low legibility.

\section{Discursive Creation}

Data 5 : Poetry 9, “Apakah ini pertanda ?”, page 79 


\begin{tabular}{|l|r|}
\hline عند الضفة اليسرى من ( السين) & SL \\
\hline Di tepi kiri perairan Seine & TL \\
\hline
\end{tabular}

On the phrase عند الضفة, has meaning in the dictionary that is "pada tepi barat" (Yunus, 1973).

In the case of translating Idhafi phrasesaغند الضفة, the translator uses a discursive creation technique, namely the translator seeks to use a temporary equivalent, namely interpreting the source language (SL) becomes "di tepi barat" which is outside the context of the source language (SL) so as to produce translation results that if suitable into the target language (TL) because the results of this translation are unpredictable.

Data 6 Poetry 12, "Kumencintaimu”, page 85

\begin{tabular}{|l|r|}
\hline وأني وراء القائق أجري & SL \\
\hline Akupun mengejar detik-detik itu & TL \\
\hline
\end{tabular}

On the phrase وراء الدقائق Was meaning in the dictionary that is"di belakang وراء الدقائق Word yang rinci" (Yunus).

In the case of translating Idhafi phrasesوراء الدقائق, the translator uses a discursive creation technique, namely the translator seeks to use a temporary equivalent, namely interpreting the source language (SL) which has meaning in the dictionary. "Di belakang yang rinci" becomes "Mengejar detik-detik" into target language(TL) which is outside the context of the source language (SL) so as to produce translation results that if suitable into the target language (TL) because the results of this translation are unpredictable..

Here are the results of the quality of translations carried out by 42 respondents.
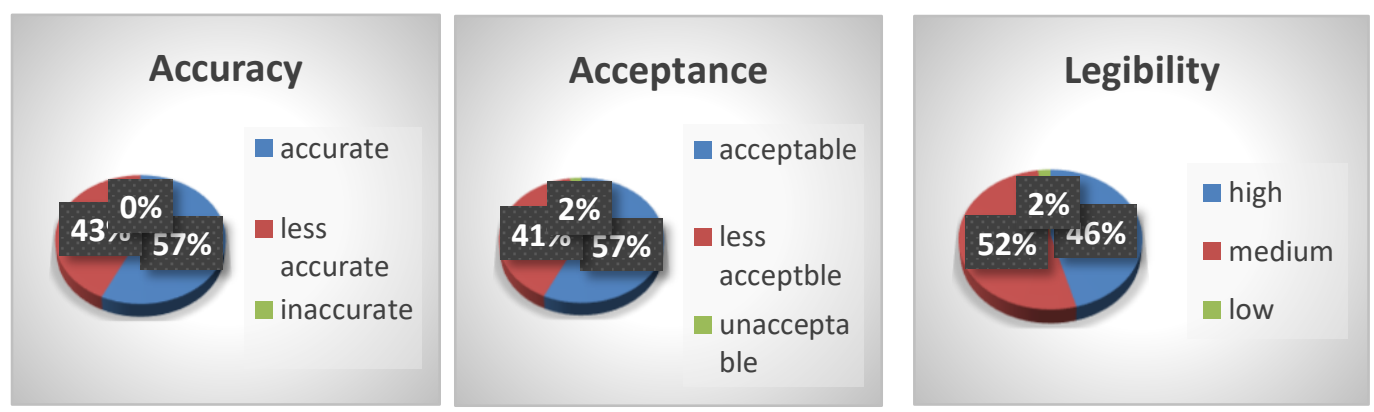

Figure 3. Quality translation of data 5 and 6.

Figure 3 dispalys that as many as 24 respondents (57.1\%) rated it very accurate. In addition, 17 respondents (40.5\%) rated it less accurate and 1 respondent (2.4\%) rated it inaccurate.

Assessment of the quality of translation using the reduction translation technique from the Acceptance aspect, 24 respondents (57.1\%) rated it acceptable, 17 respondents (40.5\%) rated it 104 
less acceptable, and there was only 1 respondent (2.4\%) who considered it unacceptable. . Then on the legibility aspect assessment, 22 respondents (52.4\%) rated the legibility high, 15 respondents $(35.7 \%)$ rated it with a moderate legibility level, and there were 5 respondents (11.9\%) rated it with low legibility.

\section{Reduction}

Data 7: Poetry 6, "Kekasihku adalah Qanun" page 69

\begin{tabular}{|l|r|}
\hline فSل من يمارسن الحب بلا إجازة & SL \\
\hline Maka setiap orang yang bercinta tanpa izin & TL \\
\hline
\end{tabular}

On the phrase بلا إجازة Word بلازة has meaning in the dictionary that is“Tanpa surat izin/ijazah/lisensi” (Al-Munawwir, 1997).

In this case the translator implies an information from the source language (SL) On the phrase بلا إجازة has meaning in the dictionary that is "Tanpa surat izin/ijazah/lisensi” becomes "tanpa izin" into target language(TL) because the meaning component is already included in the target language (TL).

Data 8: poetry 21, "Merawat kuda”, page 103

\begin{tabular}{|l|r|}
\hline Ku teguk air kedua putingmu seperti kuda & SL \\
\hline أعب من مياه نهيك كالحصان & TL \\
\hline
\end{tabular}

On the word مياه نهديك has meaning in the dictionary that is“Air dua payudara” (AlMunawwir, 1997)

The translator implies an information from the source language(SL) On the phrase مياه نهديك has meaning in the dictionary that is"Air dua payudara" becomes "Air kedua putingmu" into target language(TL) because the meaning component is already included in the target language (TL).

Here are the results of the quality of translations carried out by 42 respondents.
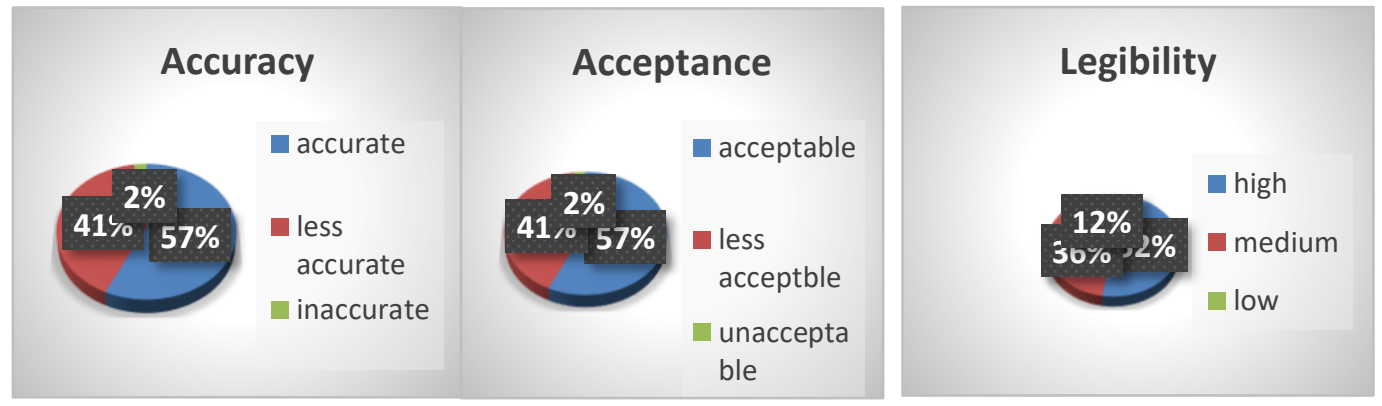

Figure 4. Quality translation of data 7 and 8

Figure 4 shows that as many as 24 respondents (57.1\%) rated the translation using the Reduction translation technique as very accurate. In addition, 17 respondents (40.5\%) rated it less accurate and 1 respondent $(2.4 \%)$ rated it inaccurate. 
In the aspect of Acceptance, 24 respondents (57.1\%) considered it acceptable, 17 respondents (40.5\%) considered it less acceptable, and there was only 1 respondent (2.4\%) who considered it unacceptable. Then on the legibility aspect, as many as 22 respondents (52.4\%) rated legibility as high, 15 respondents (35.7\%) rated it as having a moderate legibility level, and there were 5 respondents $(11.9 \%)$ rated it as low legibility.

\section{Established Equivalent}

Data 9: poetry 22 "Pada Bahr Thawil", page 105

\begin{tabular}{|l|r|}
\hline إن من أغلى هواياتي الرحيل & SL \\
\hline Sebab berkelana adalah Hobiku paling berharga & TL \\
\hline
\end{tabular}

On the phrase أغلى هواياتي, has meaning in the dictionary that is"Hobiku yang mahal” (Yunus, 1973).

In this case, the translator uses familiar terms such as the term Word "mahal" from source language (SL) replaced with the word "Berharga" because this term is commonly used in the target language (TL).

Data 10: poetry 30 “Sulit", page 121

\begin{tabular}{|l|r|}
\hline نساء الأرض لا يحصين & SL \\
\hline Wanita jagat raya tak pernah ada habisnya & TL \\
\hline
\end{tabular}

On the phrase نساء الأرض, has meaning in the dictionary that is "Perempuan bumi" (AlMunawwir, 1997).

In this case, the translator uses familiar terms such as the term Word "Perempuan bumi" from source language (SL) replaced with the word "Wanita jagat raya" because this term is commonly used in the target language (TL) and has the same meaning.

Here are the results of the quality of translations carried out by 42 respondents.
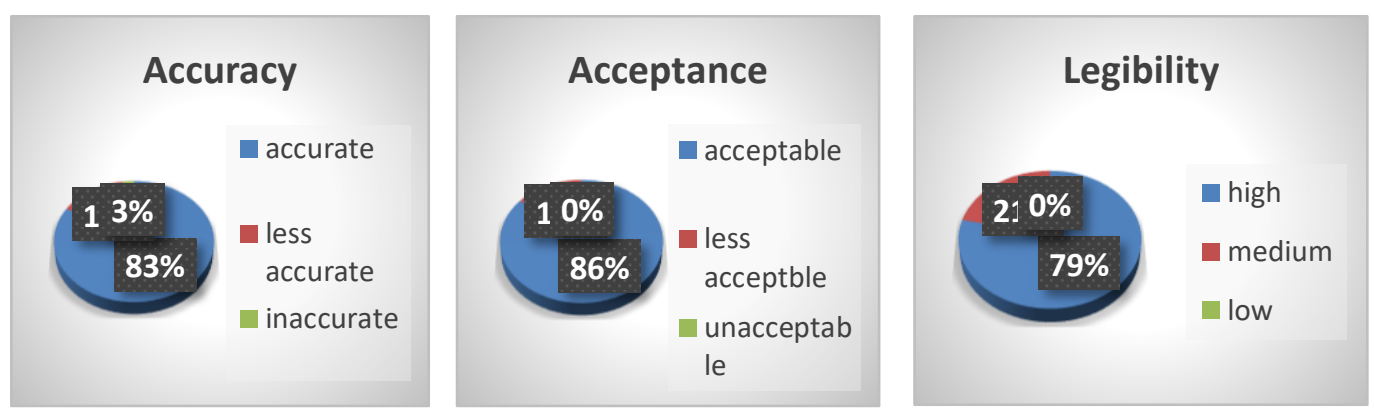

Figure 5. Quality translation of data 9 and 10

Figure 5 shows that as many as 35 respondents (83.3\%) assessed that the translation using the Ordinary Equivalence translation technique was very accurate. In addition, as many as 6 respondents $(14.3 \%)$ rated it less accurate and 1 respondent $(2.4 \%)$ rated it inaccurate. 
Assessment of the Acceptance aspect, 36 respondents (85.7\%) considered acceptable, 6 respondents (14.3\%) considered less acceptable, and only no respondents $(0 \%)$ considered unacceptable. Then the legibility aspect, as many as 33 respondents (78.6\%) rated legibility high, 9 respondents $(21.4 \%)$ rated it with a moderate level of legibility, and no respondent $(0 \%)$ rated it as low legibility.

\section{Generalization}

Data 11: poetry 6 "Kekasihku adalah Qanun" page 69

\begin{tabular}{|l|r|}
\hline مشاغبا ، أوفوضوي الفكر & SL \\
\hline Mulai dungun atau Pikiran sudah tak menentu & TL \\
\hline
\end{tabular}

On the word فوضوي الفكر has meaning in the dictionary that is "fikiran yang kacau" (AlMunawwir, 1997).

Translator refers to the use of a common term, from the term "messed" in the Source Language (SL) becomes the term "tak menentu" which is neutral in the target language (TL).

Data 12: poetry 15 “Mengapa?”, page 91

\begin{tabular}{|c|c|}
\hline وبين يدي - جين أريد - آلاف الخيارات & SL \\
\hline $\begin{array}{l}\text { Pada genggamanku - saat kumau- Terdapat beribu } \\
\text { pilihan }\end{array}$ & TL \\
\hline
\end{tabular}

Word آلاف الخيارات has meaning in the dictionary that is "Seribu pilihan" (Al-Munawwir, 1997).

Translator refers to the use of a common term, from the term "Seribu pilihan" in Source language (SL) becomes the term "beribu pilihan" which is neutral in the target language (TL).

Here are the results of the quality of translations carried out by 42 respondents.
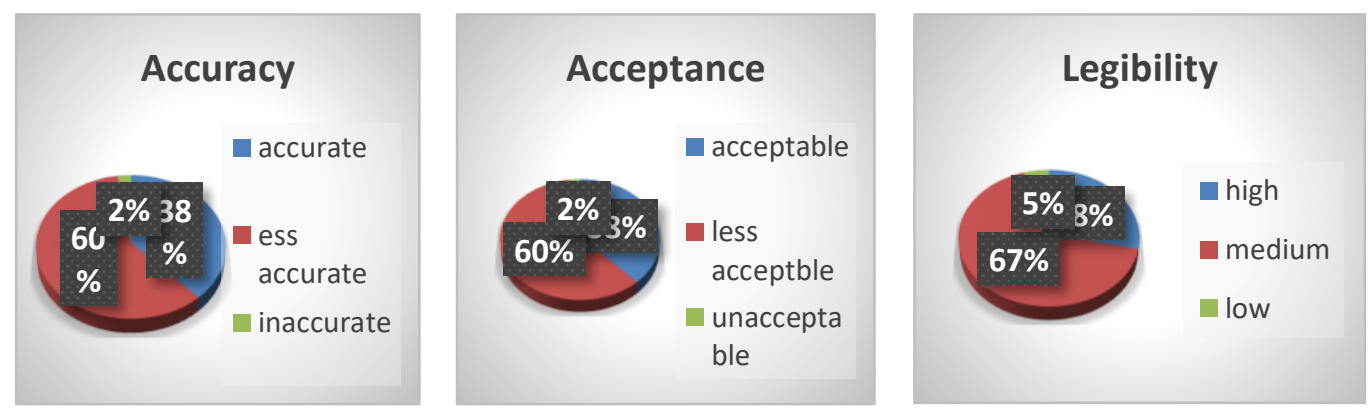

Figure 6. Quality translation of data 11 and 12

From figure 6, it can be seen that as many as 16 respondents (38.1\%) rated it very accurate. In addition, as many as 25 respondents (59.5\%) rated it less accurate and 1 respondent (2.4\%) rated it inaccurate. 
In the aspect of Acceptance, 16 respondents (38.1\%) considered it acceptable, 25 respondents (59.5\%) considered it less acceptable, and there was only 1 respondent (2.4\%) who considered it unacceptable. Then the legibility aspect. as many as 12 respondents $(28.6 \%)$ rated legibility as high, 28 respondents (66.7\%) rated it as moderate legibility, and 2 respondents $(4.8 \%)$ rated it low.

\section{Particulation}

Data 13 Poetry 3 "Aku bersaksi tiada perempuan selain engkau", Page 57

\begin{tabular}{|c|r|}
\hline استقبلت بصدرها خناجر القبيلة & SL \\
\hline Yang mengarahkan dadanya pada pisau kabilah & TL \\
\hline
\end{tabular}

On the word خناجر القبيلة has meaning in the dictionary that is "Belati suku bangsa (kabilah)" (Al-Munawwir, 1997).

The translator concretizes the meaning which has meaning in the dictionary "Belati suku bangsa (kabilah)" On the word "خناجر القبيلة" with meaning "Pisau kabilah" into target language(TL) and make the translation becomes more specific and concrete

Data 14 Poetry 3“Aku bersaksi tiada perempuan selain engkau”, Page 43

\begin{tabular}{|l|r|}
\hline Selama sepuluh tahun, seperti betahnya engkau & SL \\
\hline عشرة أعوام كما احملت & TL \\
\hline
\end{tabular}

On the word عشرة أعوام has meaning in the dictionary that is“Pada umumnya sepuluh tahun" (Al-Munawwir, 1997).

The translator concretizes the meaning which has meaning in the dictionary "Pada umumnya sepuluh tahun" On the word "عشرة أعوام" with meaning "Selama sepuluh tahun" into target language (TL) and make the translation becomes more specific and concrete .

Here are the results of the quality of translations carried out by 42 respondents.
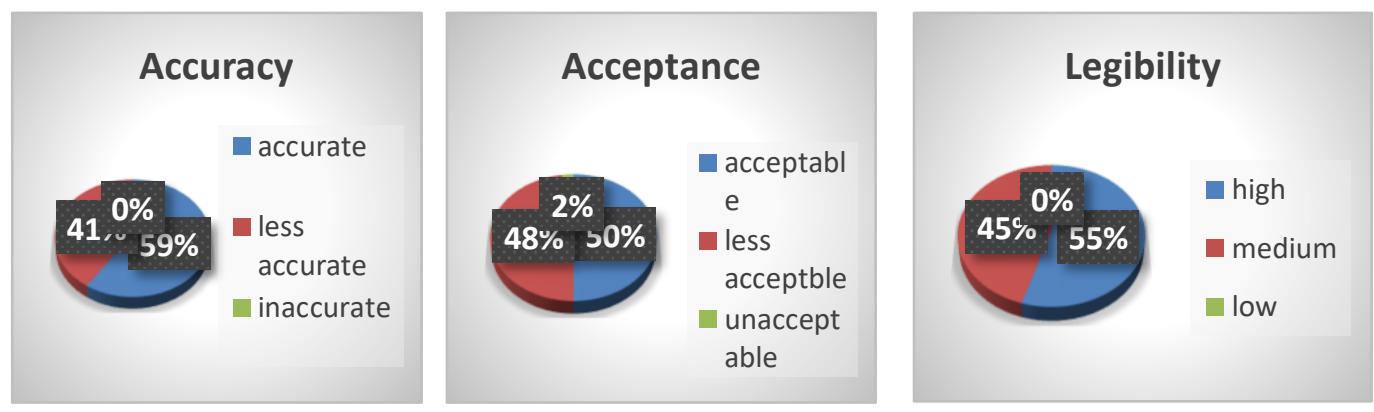

Figure 7. Quality translation of data 13 and 14

From figure 7, it can be seen that as many as 25 respondents (59.5\%) rated it very accurate. In addition, as many as 17 respondents (40.5\%) rated it less accurate and no respondent (0\%) rated it inaccurate. 
In the aspect of Acceptance, 21 respondents (50\%) rated it acceptable, 20 respondents $(47.6 \%)$ considered it less acceptable, and there was only 1 respondent $(2.4 \%)$ who considered it unacceptable. Then the legibility aspect, as many as 23 respondents (54.8\%) rated high legibility, 19 respondents $(45.2 \%)$ rated it with a moderate level of legibility, and no respondent $(0 \%)$ rated it as low legibility.

\section{Calque}

Data 15: poetry 6 "Kekasihku adalah Qanun" page 69

\begin{tabular}{|l|r|}
\hline مسؤولة عن ذلك الجنون & SL \\
\hline Harus bertanggung jawab atas kegilaanku itu & TL \\
\hline
\end{tabular}

On the word ذلك الجنون has meaning in the dictionary that is "itu kegilaan" (Yunus, 1973)

In this case, the translator transfers the phrase or word literally, as in this data in the phrase ذلك الجنون which has meaning in the dictionary "itu kegilaanku" which grammatically the translator translates becomes "kegilaanku itu" resulting in more accurate translation results.

Data 16: poetry 40 "Kau belum cukup cantik", page 141

\begin{tabular}{|c|c|}
\hline $\mid$\begin{tabular}{|l|}
$|c|$ \\
Berarti bahwa perempuan mampu menguasai nasib
\end{tabular} & TL \\
\hline para pria & \\
\hline
\end{tabular}

On the word, أقدار الرجال has meaning in the dictionary that is “Nasib laki-laki” (Yunus, 1973)

In the phrase, أقدار الرجالwhich has meaning in the dictionary, "Nasib laki-laki" which lexically the translator translates becomes "Nasib para pria" resulting in more accurate translation results.

Here are the results of the quality of translations carried out by 42 respondents.
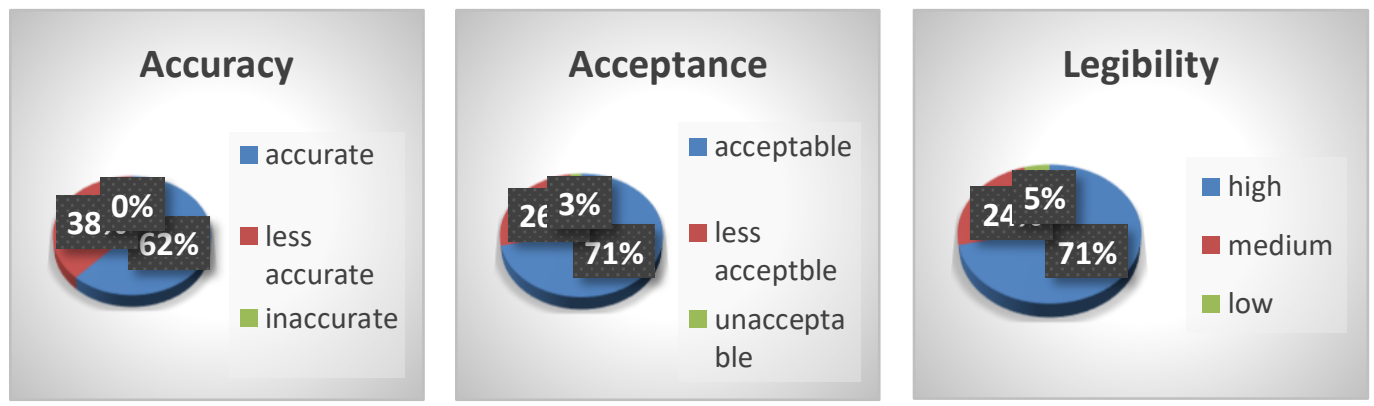

Figure 8. Quality translation of data 15 and 16

From the diagram above, it can be seen that as many as 26 respondents $(61.9 \%)$ rated it very accurate. In addition, as many as 16 respondents (38.1\%) rated it less accurate and no respondent $(0 \%)$ rated it inaccurate. 
Assessment of the Acceptance aspect, 30 respondents (71.4\%) considered acceptable, 11 respondents (26.2\%) considered less acceptable, and there was only 1 respondent (2.4\%) who considered not acceptable. Then on the aspect of legibility. In the legibility aspect assessment, as many as 30 respondents $(71.4 \%)$ rated the legibility high, 10 respondents $(23.8 \%)$ rated it with a moderate level of legibility, and there were 4 respondents (4.8\%) rated it with low legibility.

\section{Modulation}

Data 17: poetry 1 "Prolog", page 39

\begin{tabular}{|l|r|}
\hline وتدخل وقت الكتابة & SL \\
\hline Yang menyelinap di kala aku menulis & TL \\
\hline
\end{tabular}

On the phrase وقت الكتابة Word وقت الكتابة, has meaning in the dictionary that is "Waktu menulis"

In the case of translating Idhafi phrasesوقت الكتابة, the translator uses the Modulation Technique, which is a technique with a style of changing the focal point of view, namely On the phrase which has meaning in the dictionary "waktu meluis" in the source language (SL) then the translator changes the point of view of focus by interpreting it becomes " di kala aku menulis" into target language (TL).

Data 18: poetry 4 "Sudah takdir engkau sebagai perempuan", page 63

\begin{tabular}{|l|r|}
\hline قدر أنت بشكل امرأتي & SL \\
\hline Sudah takdir engkau sebagai perempuan & TL \\
\hline
\end{tabular}

On the word بشكل امرأة has meaning in the dictionary that is "Secara perempuan" (Yunus, 1973)

In the case of translating Idhafi phrasesat بشكل امرأة, translator changes focus point of view on the phrase بشكل امرأة, which has meaning in the dictionary "Secara perempuan" in the source language (SL) then the translator changes the point of view of focus by interpreting it becomes " Sebagai perempuan" into target language(TL).

Here are the results of the quality of translations carried out by 42 respondents.
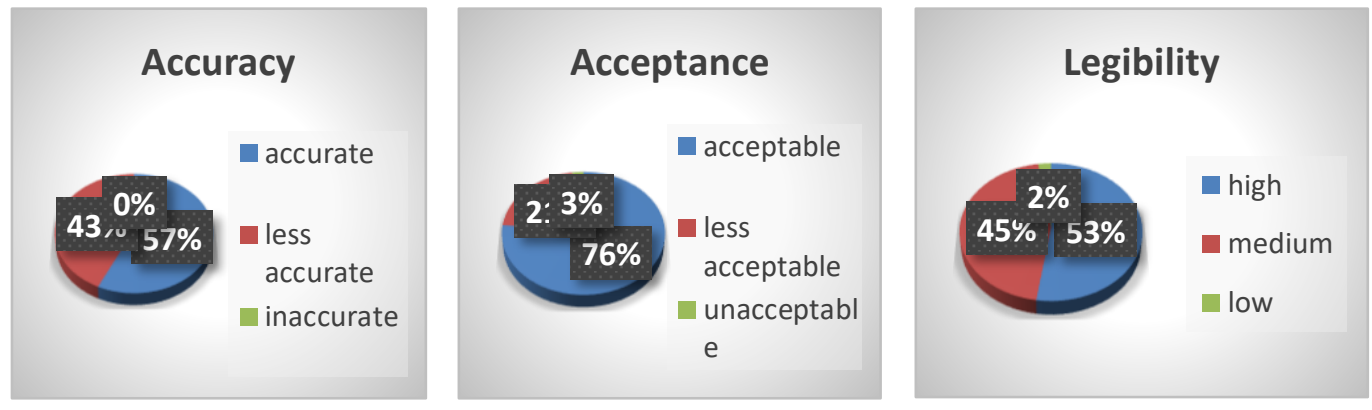
Figure 9. Quality translation of data 17 and 18

Figure 9 indicates that as many as 24 respondents (57.1\%) rated it very accurate. In addition, as many as 18 respondents (42.9\%) rated it less accurate and no respondents $(0 \%)$ rated it inaccurate.

From the acceptance aspect, 32 respondents (76.2\%) considered acceptable, 9 respondents $(21.4 \%)$ considered less acceptable, and 1 respondent $(2.4 \%)$ considered unacceptable. The legibility aspect assessment was 22 respondents $(52,4 \%)$ rated high legibility, 19 respondents (45.2\%) rated it with moderate legibility level, and there was 1 respondent (2.4\%) rated low legibility.

\section{Variation}

Data 19 Poetry 31 "Idiot”, Page 123

\begin{tabular}{|l|r|}
\hline حين شطبتك من دفتر الذكرياتي & SL \\
\hline Saat ku hapus Catatan kenangan tentang dirimu & TL \\
\hline
\end{tabular}

On the word دفتر ذاكرتي has meaning in the dictionary that is "Buku ingatan" (Yunus, 1973).

On the phrase دفتر ذاكرتي which has meaning "Buku kenangan" then the translator translates it becomes "catatan kenangan" into target language(TL), related to style, social dialect, or geographical dialect.

Data 20 Poetry 32 "Suratjaminan", Page 125

\begin{tabular}{|l|r|}
\hline & SL \\
\hline ini & Aku bersaksi-hingga dengan tulisan pada setiap baris \\
\hline
\end{tabular}

On the phrase هذي السطور Word هذي السطور heaning in the dictionary that is" Garis ini” (Yunus, 1973).

On the phrase هذي السطور which has meaning "Garis ini" then the translator translates it becomes "Setiap baris ini" into target language (TL), related to style, social dialect, or geographical dialect.

Here are the results of the quality of translations carried out by 42 respondents. 

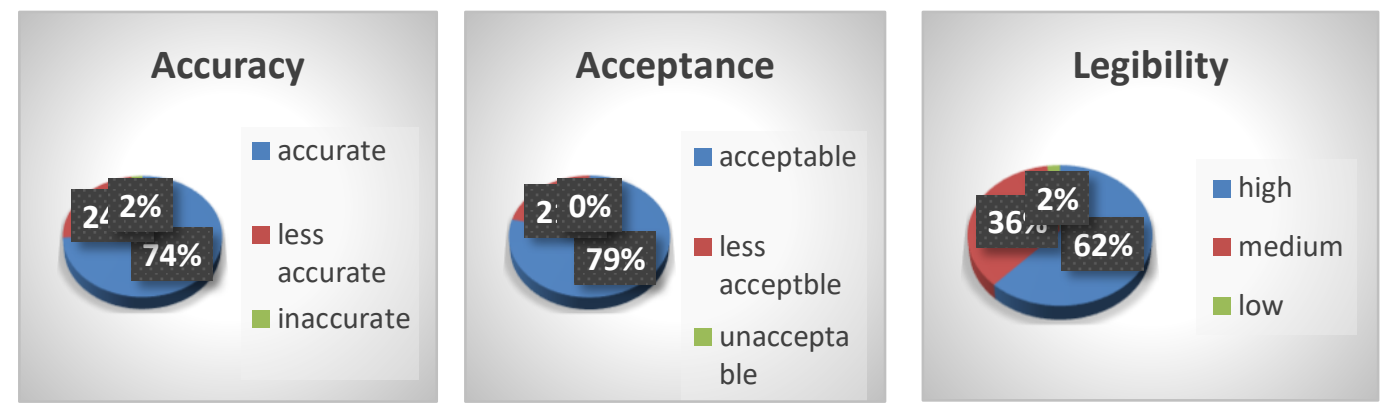

Figure 10. Quality translation of data 19 and 20

From figure 10, it shows that 31 respondents (73.8\%) rated it very accurate. In addition, as many as 10 respondents (23.8\%) rated Variation as less accurate and only 1 respondent $(2.4 \%)$ rated it inaccurate.

From the acceptance aspect, 33 respondents (78.6\%) rated it acceptable, 9 respondents (21.4\%) considered it less acceptable, and no respondents $(0 \%)$ considered it unacceptable. Aspect assessment as many as 26 respondents (61.9\%) rated legibility high, 15 respondents $(35.7 \%)$ rated it with a moderate level of legibility, and there was 1 respondent $(2.4 \%)$ rated it as low legibility.

\section{Compensation}

Data 21 : poetry 2 "Pengadilan", page 41

\begin{tabular}{|c|c|}
\hline وكل خائفة أهديتها وطنا & SL \\
\hline $\begin{array}{l}\text { Setiap perempuan yang ketakutan, ku beri ia tempat } \\
\text { tinggal }\end{array}$ & $\mathrm{TL}$ \\
\hline
\end{tabular}

On the phrase كل خل خلئفة Word has meaning in the dictionary that is "Setiap yang ketakutan" (Al-Munawwir, 1997).

In the case of translating Idhafi phrases كل خائفة, the translator uses the Compensation Technique, which is a translation that focuses on the information to be conveyed, in this case, the translator focuses on the context of the target language (TL) which is then translated becomes"Setiap perempuan yang ketakutan “ which is Source language (SL) "كل خائفة which literally means "Setiap yang ketakutan" then replaced by stylistic elements or sentence structure so as to produce more precise information on the results of the target language (TL) translation.

Data 22 : poetry 3 "Aku bersaksi tiada perempuan selain engkau", page 57

\begin{tabular}{|l|r|}
\hline & SL \\
\hline Perempuan yang selalu seperti anak kecil & TL \\
\hline
\end{tabular}

On the phrase الدائمة الطفولة has meaning in the dictionary that is "Selalu anak-anak kecil" (Al-Munawwir, 1997). 
In the case of translating Idhafi phrasesaالدائمة الطفولة, the translator uses the Compensation Technique, which is a translation that focuses on the information to be conveyed, in this case, the translator focuses on the context of the target language (TL) which is then translated becomes "Perempuan yang selalu seperti anak kecil " which is Source language (SL)“"الدائمة الطفولة"wich literally means"Selalu anak-anak kecil "then replaced by stylistic elements or sentence structure so as to produce more precise information on the results of the target language (TL) translation.

Here are the results of the quality of translations carried out by 42 respondents.
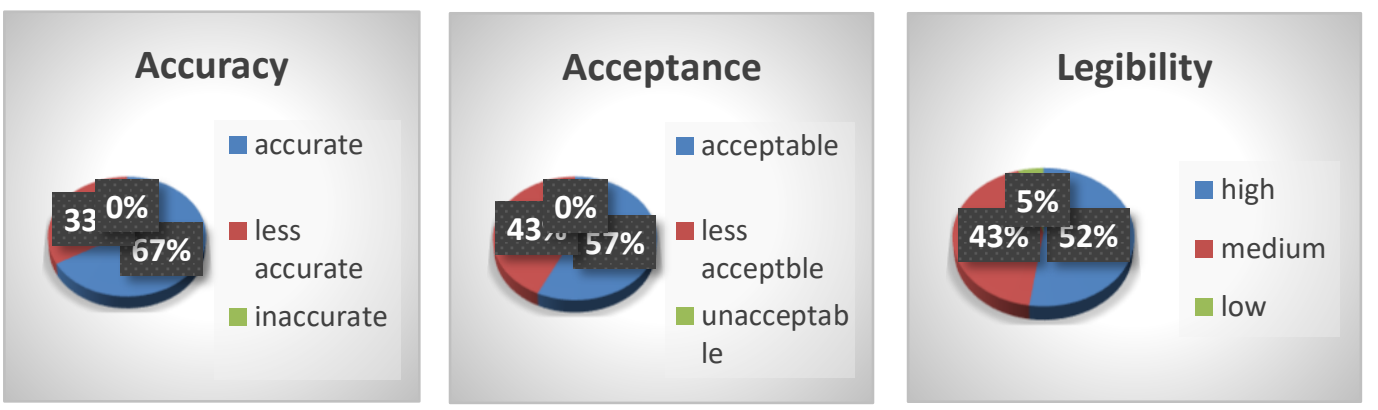

Figure 11. Quality translation of data 21 and 22

Figure 11 indicates that 28 respondents (66.7\%) rated the translation using the Compensation translation technique as very accurate. In addition, as many as 14 respondents (33.3\%) assessed that the translation using the Compensation translation technique was less accurate and no respondent $(0 \%)$ assessed that the translation using the Compensation translation technique was inaccurate.

Assessment of translation quality using the Compensation translation technique from the Acceptance aspect, 24 respondents (57.1\%) rated it acceptable, 18 respondents (42.9\%) rated it less acceptable, and only no respondent (0\%) considered it unacceptable. In addition to the aspects of Accuracy and Acceptance, the assessment of the quality of translation using the Compensation translation technique is also reviewed from the legibility aspect. The assessment of the legibility aspect of the data using this Compensation translation technique, as many as 22 respondents $(52.4 \%)$ rated legibility high, 18 respondents $(42.9 \%)$ rated the legibility level moderate, and there were 2 respondents (4.8\%) rated with low legibility.

\section{Amplification}

Data 23 Poetry 3 "Aku bersaksi tiada perempuan selain engkau”, Page 55

\begin{tabular}{|l|r|}
\hline وألف ألف كوكب يدور & SL \\
\hline Ribuan galaksi berotasi & TL \\
\hline
\end{tabular}

On the phrase ألف ألف كوكب Was meaning in the dictionary that is "Seribu, seribu bintang" (Yunus, 1973). 
In the case of translating Idhafi phrasestألف ألف كوكب, the translator uses the Amplification Technique, namely the translator makes explicit or paraphrases an implicit information, namely in this case there is a phrase in the source language (SL) " which has meaning in the dictionary "Seribu,seribu bintang." The translator then changed the meaning into "ribuan galaksi" to the targeted language (TL).

Data 24: poetry 36 "Teruntuk separuh perempuan pencinta”, page 133

\begin{tabular}{|l|r|}
\hline تحركي خطوة ، يا نصف عاشقة & SL \\
\hline Majulah selangkah, wahai perempuan separuh pencinta & TL \\
\hline
\end{tabular}

On the phrase أنصاف عشاق Word has meaning in the dictionary that is" Separuh kekasih" (Yunus, 1973).

In the case of translating Idhafi phrasestأنصاف عاشق, the translator uses the amplification technique, namely the translator makes explicit or paraphrases an implicit information, namely in this case there is a phrase in the SL "أنصاف عاشقة" which has meaning in the dictionary "Separuh kekasih". The translation than changed into "Separuh pencinta" for the TL.

Here are the results of the quality of translations carried out by 42 respondents
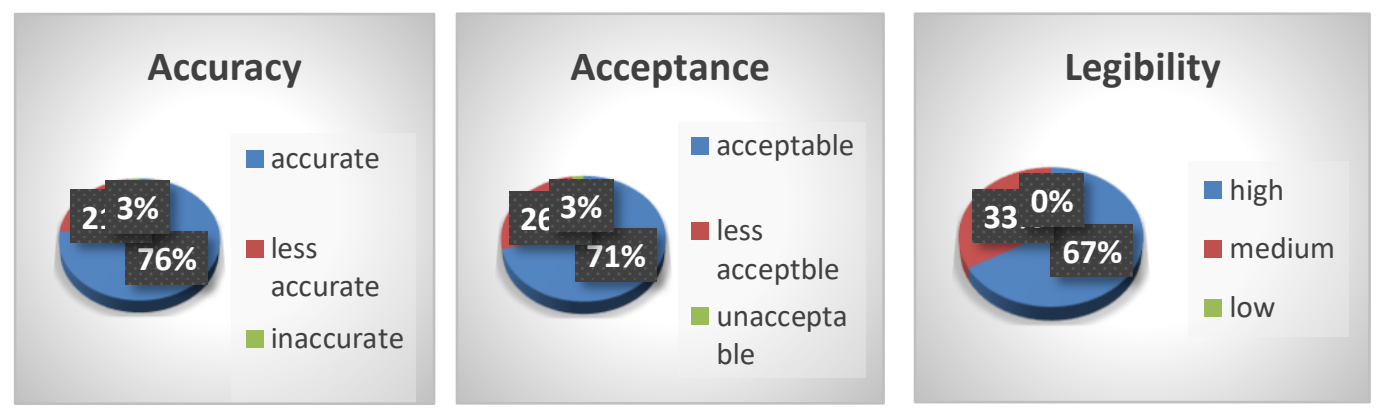

Figure 12. Quality translation of data 23 and 24

Figure 12 shows that 32 respondents $(76.2 \%)$ rated it very accurate. In addition, as many as 9 respondents $(21.4 \%)$ considered it less accurate and there was only 1 respondent $(2.4 \%)$ rated the translation using the Amplification translation technique as inaccurate.

From the aspect of Acceptance, 30 respondents (71.4\%) considered it acceptable, 11 respondents $(26.2 \%)$ considered it less acceptable, and there was only 1 respondent $(2.4 \%)$ who considered it unacceptable. From the legibility aspect, 28 respondents (66.7\%) rated legibility as high, 14 respondents (33.3\%) rated it as having a moderate legibility level, and no respondent $(0 \%)$ rated it as low legibility.

\section{Borrowing}

In the borrowing translation technique, the researcher analyzes the 1 type of phrase Data 25: poetry 36 "Teruntuk separuh perempuan pencinta", page 133 


\begin{tabular}{|c|r|}
\hline Yang terbebas dari jeratan hokum Ahlul kahfi, selain & SL \\
\hline Yحررت من حكم أهل الكهف إلا أنت & TL \\
\hline
\end{tabular}

In this data, the translator translates using a borrowing technique, namely:, أهل الكهف. Word in the dictionary has meaning "keluarga, penduduk, pantas, layak dan ahli", but on the word الكهف it means "gua" (Yunus, 1973).

On the translation of Idhafi phrases, أهل الكهف translator uses borrowing technique. Translator borrows expressions أهل from the source language (SL) to be translated into the target language (TL), so that the translator keeps translating this phrase with the expression "ahlul", and also the translator borrowed the phrase الكهف from source language(SL) to be translated into target language (TL) so that translators keep translating these phrases with expressions "kahfi". This page was created because of the expression "ahlul" and "kahfi" more precisely translated using borrowing techniques to facilitate the meaning and terms "ahlul kahfi" popular among Indonesian people.

Here are the results of the quality of translations carried out by 42 respondents.
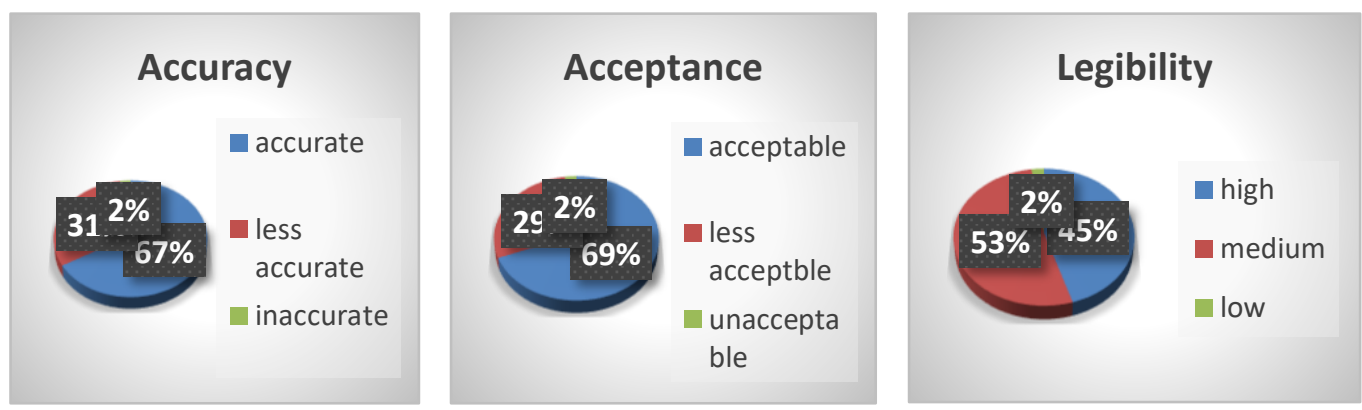

Figure 13. Quality translation of data 25 and 26

Figure 13 concludes that 28 respondents (66.7\%) rated it very accurate. In addition, as many as 13 respondents (31\%) rated it less accurate, and only 1 respondent $(2.4 \%)$ rated it inaccurately.

From the Acceptance aspect, 29 respondents (69\%) rated it acceptable, 12 respondents $28.6 \%$ ) considered it less acceptable, and there was only 1 respondent (2.4\%) who considered it unacceptable. Then from the aspect as many as 19 respondents (45.2\%) rated legibility as high, 22 respondents $(52.4 \%)$ rated it with a moderate level of legibility, and there was only 1 respondent (2.4\%) rated it with low legibility.

\section{Linguistic Compression}

In the linguistic compression translation technique, the researcher analyzes 1 type of phrase 
Data 26: poetry "Maukah kau duduk sebentar saja", page 147

\begin{tabular}{|l|r|}
\hline & SL \\
\hline Tak akan mati semudah itu & TL \\
\hline
\end{tabular}

In this data, there are Idhafi phrases which are translated using linguistic compression, namely, تلك السهولة. Phrase تلك السهولة in the dictionary has meaning "Kemudahan itu” (Yunus, 1973).

On the translation of Idhafi phrases تلكهولة, the translator uses a linguistic compression technique that simplifies the linguistic elements from the source language (SL), namely On the phrase "تلك السهولة" which has meaning in the dictionary "kemudahan itu" then the translator simplifies the linguistic element becomes meaning "semudah itu" into the target language (TL) to make it easier to understand.

Here are the results of the quality of translations carried out by 42 respondents.
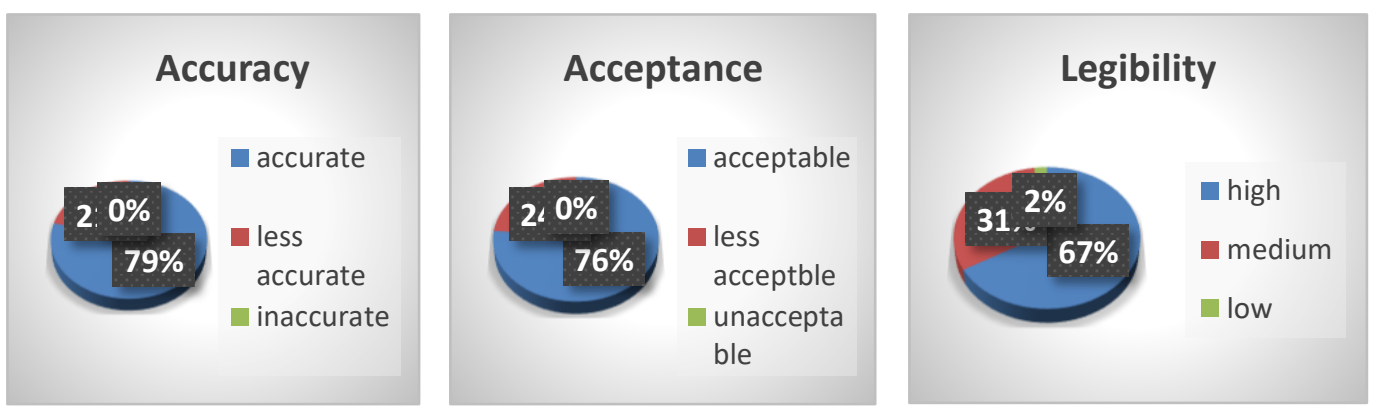

Figure 14. Quality translation of data 26

Figure 14 indicates that 33 respondents (78.6\%) rated the translation using the Linguistic Compression translation technique as very accurate. In addition, as many as 9 respondents $(21.4 \%)$ assessed that the translation using the Linguistic Compression translation technique was less accurate and none of the respondents $(0 \%)$ assessed that the translation using the Linguistic Compression translation technique was inaccurate.

Assessment of translation quality using the Linguistic Compression translation technique from the Acceptance aspect, 32 respondents (76.2\%) rated it acceptable, 10 respondents 23.8\%) rated it less acceptable, and no respondent (0\%) considered it unacceptable. In addition to the aspects of Accuracy and Acceptance, the assessment of the quality of translation using the Linguistic Compression translation technique is also reviewed from the legibility aspect. In the assessment of the legibility aspect of the data using this linguistic compression translation technique, as many as 28 respondents $(66.7 \%)$ rated readability as high, 13 respondents (31\%) rated it with a moderate legibility level, and there was only 1 respondent $(2.4 \%)$ rated with low legibility.

\section{Transposition}

In the transposition translation technique, the researcher analyzes the 1 type of phrase. 
Data 27 : poetry 37 “Buku yang dibaca”, page 135

\begin{tabular}{|l|r|}
\hline & SL \\
\hline Yang aku ucapkan saat kita di depan pintu & TL ونحن عند الباب \\
\hline
\end{tabular}

In this data, there are Idhafi phrases which are translated using transposition, namely, عند عند in the dictionary has meaning "Pada ketika pintu” (Yunus, 1973).

On the translation of Idhafi phrases عند الباب, the translator uses the transposition technique, which is a technique that is done by changing the categories of grammar, starting from the sentence structure, or units from the source language (SL) namely On the phrase عند الباب has meaning in the dictionary "pada ketika pintu " then the translator changes the structure or unit of the source language (SL) then translates becomes " di depan pintu " into the target language (TL).

Here are the results of the quality of translations carried out by 42 respondents.
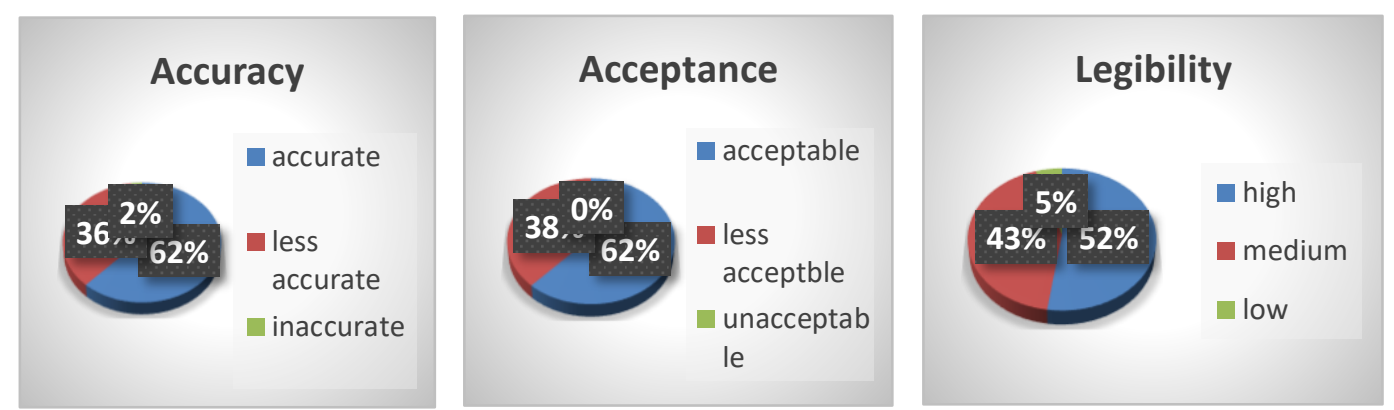

Figure 15. Quality translation of data 27

From the diagram above, it can be seen that as many as 26 respondents (61.9\%) rated the translation using the Transpositional translation technique as very accurate. In addition, as many as 15 respondents (35.7\%) rated the translation using the transpositional translation technique as less accurate. Only 1 respondent (2.4\%) assessed that the translation using the transpositional translation technique was inaccurate.

Assessment of the quality of translation using the transposition translation technique from the acceptance aspect, 26 respondents (61.9\%) rated it acceptable, 16 respondents (38.1\%) rated it less acceptable, and no respondent $(0 \%)$ considered it unacceptable. In addition to the aspects of accuracy and acceptance, the assessment of the quality of translation using the transposition translation technique is also reviewed from the legibility aspect. Evaluation of the legibility aspect of the data using this transposition translation technique, as many as 22 respondents $(52.4 \%)$ rated high readability, 18 respondents (42.9\%) rated the legibility level moderate, and there was only 2 respondents $(4.8 \%)$ judge with low legibility. 
Conclusion

From the 15 translation techniques used by translators in translating poetry Asyhadu An La Imraata Illa Anti by Nizar Qabbani, the established equivalent technique and the linguistic compression technique are considered to have good quality in conveying the intent, message, and purpose for the reader in the targeted language. The equivalence technique is usually considered to have good translation quality because it has the highest value in three aspects of assessing the quality of translation including, the accuracy aspect has a score of $83.3 \%$ with indicators that the message can be conveyed accurately into the target language, there is no meaning digression, then in the acceptance aspect it has a score of $85.7 \%$ with the translation indicator becoming natural. After all, it follows the rules and culture of the target language, and in the legibility aspect, it has a $78.6 \%$ score with the translation indicators easy to understand by readers.

In addition to the usual equivalence translation technique, the linguistic compression technique has good translation quality because it has the highest score on three aspects of assessment. The quality of translation includes, the accuracy aspect has a score of $78.6 \%$ with indicators that the message can be conveyed accurately into the target language, there is no meaning digression, then the acceptability aspect has a score of $76.2 \%$ with the indicator of translation being felt natural because it is following the rules and culture of the target language. The readability aspect has a score of $66.7 \%$, with indicators of translation that readers easily understand.

\section{References}

Al-Ghadeer, M. (2007). Arabic Poetry: Trajectories of Modernity and Tradition. In Journal of Arabic Literature (Vol. 38). https://doi.org/10.1163/157006407783182308

Al-Munawwir, A. W. (1997). Kamus Al-Munawwir Arab-Indonesia Terlengkap. Pustaka Progressif. Yogyakarta.

Bassnett, S. (2013). Translation studies. Routledge.

Doğru, İ. (2017). Yahya Kemal and Nizar Qabbani: Two Poet-Diplomats in Spain and "Andalus" in their Poems. CLEaR, 4(2), 20-33. https://doi.org/10.1515/clear-2017-0009

Faturrahman, M. I., Yoyo, Y., \& Zaini, A. R. (2020). Technique and Quality Translation of Idhafi in The Matan Hadits of Arba'in al-Nawawi. Jurnal Al Bayan: Jurnal Jurusan Pendidikan Bahasa Arab, 12(2), 208-224. https://doi.org/10.24042/albayan.v12i2.5882

Gruendler, B. (2003). Medieval Arabic praise poetry: Ibn al-Rûmî and the patron's redemption. In RoutledgeCurzon studies in Arabic and Middle-Eastern literatures. Retrieved from http://www.loc.gov/catdir/enhancements/fy0652/2002026873-d.html

Lestari, W., Yoyo, Y., \& Zaini, A. R. (2020). Amplification and Description Techniques in the Translation of Arabic Phrases in Matan Al-Ghayah wa Al-Taqrib. Izdihar : Journal of Arabic Language Teaching, Linguistics, and Literature, 3(2), 113-128. https://doi.org/10.22219/jiz.v3i2.12337

Lughod, I. A. (1963). Arab Rediscovery of Europe: A Study in Cultural Encounters. Princeton University Press.

Molina, L., \& Albir, A. H. (2002). Translation techniques revisited: A dynamic and functionalist approach. Meta, 47(4), 498-512. https://doi.org/10.7202/008033ar 
Moradi, M., \& Karimi, P. (2012). Manifestations of love and women in the Nizar Qabbani's. Contemporary Literature Studies, 4(13), 81-101.

White, H. (1978). The Historical Text as Literary Artifact. Tropics of Discourse: Essays in Cultural Criticism., 3(3), 81-100.

Yan, C., \& Huang, J. (2014). The Culture Turn in Translation Studies. Open Journal of Modern Linguistics, 04(04), 487-494. https://doi.org/10.4236/ojml.2014.44041

Yoyo. (2018). Neo-patriarchy and the Problem of the arab Crisis: A CritiCal study on hisham sharabi's Works. Qudus International Journal of Islamic Studies, 6(2), 251-267. https://doi.org/10.21043/qijis.v6i2.3808

Yoyo, Y., Ahimsa Putra, Heddy Shri Manshur, F. M., \& Muti'ah, S. (2012). Tren Pemikiran Intelektual Muslim Kontemporer Di Timur Tengah Pasca-Difitisme 1967. Kawistara, 2(3), 225-328. https://doi.org/10.22146/kawistara.3941

Yoyo, Y., \& Mukhlis, A. (2019). Historiography of the Arabic Grammar in Europe: The Legacy of Wright's Arabic Grammar. 1st International Conference on Progressive Civil Society (IConProCS 2019). https://doi.org/10.2991/iconprocs-19.2019.45

Yunus, M. (1973). Kamus Arab-indonesia. Yayasan Penyelenggara Penterjemah/Pentafsir al Qur'an.

Zeidan, J., \& Moreh, S. (1979). Modern Arabic Poetry 1800-1970 [The Development of Its Forms and Themes under the Influence of Western Literature]. In Journal of the American Oriental Society (Vol. 99). https://doi.org/10.2307/598982Anisa, A., Satwikasari, A. F., \& Saputra, M. S. A. (2019). Penerapan Konsep Arsitektur Tradisional Sunda Pada Desain Tapak Lanskap Dan Bangunan Fasilitas Resort. Prosiding Semnastek. 